\title{
The Effect of Ophiocephalus striatus sp. Extract on Nitric Oxide in Ischemic Stroke Model
}

\author{
Iskandar Nasution ${ }^{1 \dagger *}$, Hasan Sjahrir ${ }^{1 \dagger}$, Syafruddin Ilyas ${ }^{2 \dagger}$, Muhammad Ichwan ${ }^{3 \dagger}$ \\ ${ }^{1}$ Department of Neurology, Faculty of Medicine, University of Sumatera Utara, Haji Adam Malik General Hospital, Medan, \\ Indonesia; ${ }^{2}$ Department of Biology, Faculty of Mathematics and Natural Science, University of Sumatera Utara, Medan, \\ Indonesia; ${ }^{3}$ Department of Pharmacology and Therapeutics, Faculty of Medicine, University of Sumatera Utara, Haji Adam \\ Malik General Hospital, Medan, Indonesia \\ ${ }^{\dagger}$ These authors contributed equally to this work.
}

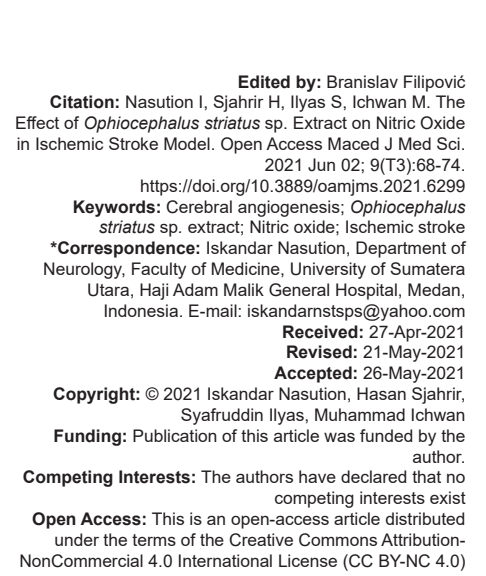

\section{Abstract}

BACKGROUND: One of alternative medicine in stroke therapy is Ophiocephalus striatus sp. extract. The nutrients contained in the $\mathrm{O}$. striatus sp. extract, namely amino acids, fatty acids, cuprum, and zinc, are useful for the process of angiogenesis in poststroke patients through increased endothelial nitric oxide synthase.

AIM: We hypothesized that there was an effect of giving O. striatus sp. extract to cerebral angiogenesis process of Sprague Dawley rats ischemic stroke models through the level of NO.

METHODS: This was evidenced by conducting experimental studies on rats ischemic stroke models which were divided into five groups, (a) K (-) group (no ligation, no treatment), (b) K (+) group (ligation, no treatment), (c) P1 group (ligation, $200 \mathrm{mg}$ extract), (d) P2 group (ligation, $400 \mathrm{mg}$ extract), and (e) P3 group (ligation, $800 \mathrm{mg}$ extract). Then blood sample was taken on day 3 to assess levels of NO.

RESULTS: There was increased level of NO in P1 $(p=0.001), P 2(p<0.001)$, and P3 $(p<0.001)$ groups compared to $\mathrm{K}(+)$ group. The level of $\mathrm{NO}$ increases along with the increasing dose of $\mathrm{O}$. striatus sp. extract. Histological examination revealed that there was formation of new blood vessel in the P1, P2, and P3 groups compared to K (+) group.

CONCLUSION: Our study showed that O. striatus sp. extract improves cerebral angiogenesis in rat models of ischemic stroke.

\section{Introduction}

Stroke is a major cause of disability in the world, both in developed and developing countries. Stroke also requires serious attention because it can have an impact on the socio-economic [1].

Various studies have been developed in search of more effective stroke therapy [2]. Oentaryo et al. have been carried out research about alternative medicine in the treatment of ischemic stroke and one of them is Ophiocephalus striatus sp. extract [3]. The potential nutrient possessed by 0 . striatus $\mathrm{sp}$. is also useful for the process of angiogenesis in post-stroke patients. The nutrient consists of proteins, especially albumin and amino acids, fatty acids (palmitic acid, oleic acid, linoleic acid, and arachidonic acid), minerals, especially zinc $(\mathrm{Zn})$, cuprum $(\mathrm{Cu})$, and Vitamins (A and B6). The role of $O$. striatus $\mathrm{sp}$. in the formation of angiogenesis through increasing endothelial nitric oxide (eNO) synthase which is the pathway for angiogenesis formation [4]. Studies by Rahayu et al. and Pudjonarko and Abidin found that the extract of $O$. striatus sp. with its various ingredients is very important in the process of angiogenesis. Research related to $O$. striatus $\mathrm{sp}$. extract, especially in Indonesia, so far has been limited and focused on the process of wound healing, but there has never been specific research and analysis of the effects of $O$. striatus $\mathrm{sp}$. extract on cerebral angiogenesis [4], [5].

We hypothesized that there was an effect of O. striatus sp. extract on the cerebral angiogenesis process of Sprague Dawley rats ischemic stroke models on the levels of NO. The content of amino acids in $O$. striatus sp. extract is arginine. Arginine is a coenzyme in the formation of eNO synthase (eNOS) to NO. NO has several benefits in ischemic stroke therapy as a vasodilator, inhibits aggregation and platelet adhesion, inhibits leukocyte adhesion and chemotaxis, and inhibits N-Methyl-D-aspartate [5]. In this study, we analyzed the effect of administering $O$. striatus $\mathrm{sp}$. extract on the levels of $\mathrm{NO}$ in cerebral angiogenesis of rat ischemic stroke models. This is the first study that has proven the effect of administered 0 . striatus $\mathrm{sp}$. extract to increase cerebral angiogenesis in ischemic stroke models histopathologically. 


\section{Methods}

\section{Animal preparation}

This study used experimental animals of the Sprague Dawley strain rat. Inclusion criteria are (1) Male rats, (2) 2.5-3 months of age, (3) body weight between 300 and $450 \mathrm{~g}$, (4) Healthy and active rats (eating and drinking, no injuries, no body defects, or hair loss). The purpose of this study was to prove the effect of $\mathrm{O}$. striatus sp. extract on $\mathrm{NO}$ levels in the cerebral angiogenesis process of Sprague Dawley rat ischemic stroke model.

Sprague Dawley male rats were selected randomly. Experimental animals were divided into 5 treatment groups and each group consisted of 5 rats, which is: (1) K (-) group (no ligation, no treatment), (2) K $(+)$ group (ligation, no treatment), (3) P1 group (ligation, $200 \mathrm{mg}$ extract), (4) P2 group (ligation, $400 \mathrm{mg}$ extract), (5) P3 group (ligation, $800 \mathrm{mg}$ extract).

The stroke induction method was done by the unilateral carotid artery occlusion (UCAO) method, which was the internal and external carotid arteries of ischemic stroke models on the left side. The anesthetized procedure used ketamine at a dose of $40 \mathrm{mg} / \mathrm{BW}$. The rats were fixed in a supine position above the surgical site. Furthermore, the hair on the neck was shaved then the skin of the neck was cleaned using $70 \%$ alcohol with cotton and given an antiseptic to prevent infection during incision. After that, an incision was made using a scalpel in the midline of the neck vertically $2-3 \mathrm{~cm}$, looking for a carotid artery located at the lateral trachea. Carotid artery ligated for 45 min using 6.0 Prolene threads. After $40 \mathrm{~min}$, the bond of Prolene was released. Then the incision wound was closed and sutured using catgut. After that, the stitches were smeared with antiseptic, then the wound was closed with sterile gauze [6], [7]. On the $3^{\text {rd }}$ day, each of rats ischemic stroke models was sacrificed by decapitation and brain tissue in the right hemisphere was taken for histological examination.

Neurological deficits are divided into 5 grades, which was Grade 0: No deficit seen, Grade 1: Front flexion, Grade 2: Cause nondirectional movement when the tail is pulled, Grade 3: Circular and circular movements, Grade 4: Decreased awareness, and Grade 5: Death. Rats ischemic stroke models with neurological deficits 4 and 5 will be excluded [7], [8]. All animal procedures were based on the Helsinki Declaration and approved by the Animal Research Ethics Commission, Faculty of Mathematics and Natural Sciences, University of North Sumatra.

\section{O. striatus sp. extract}

The dose of O. striatus sp. extract $\left(\right.$ VipAlbumin $\left.{ }^{\circledR}\right)$ given to rats ischemic stroke models was calculated based on formula animal equivalent dose (AED). With an estimated animal weight of Sprague Dawley rats were average of $250 \mathrm{mg}$, we found an AED were $400 \mathrm{mg}$.

O. striatus sp. extract $100 \%$ were given at a dose of $200 \mathrm{mg} / \mathrm{day}, 400 \mathrm{mg} / \mathrm{day}$, and $800 \mathrm{mg} / \mathrm{day}$. The administration of $100 \%$ O. striatus sp. extract was given intraoral by inserting directly into the stomach of the rat using a feeding tube (sonde) every $24 \mathrm{~h}$ [9], [10]. Administration of $O$. striatus $\mathrm{sp}$. is performed for 3 days after carotid artery ligation. The flowchart of research can be seen in Figure 1.

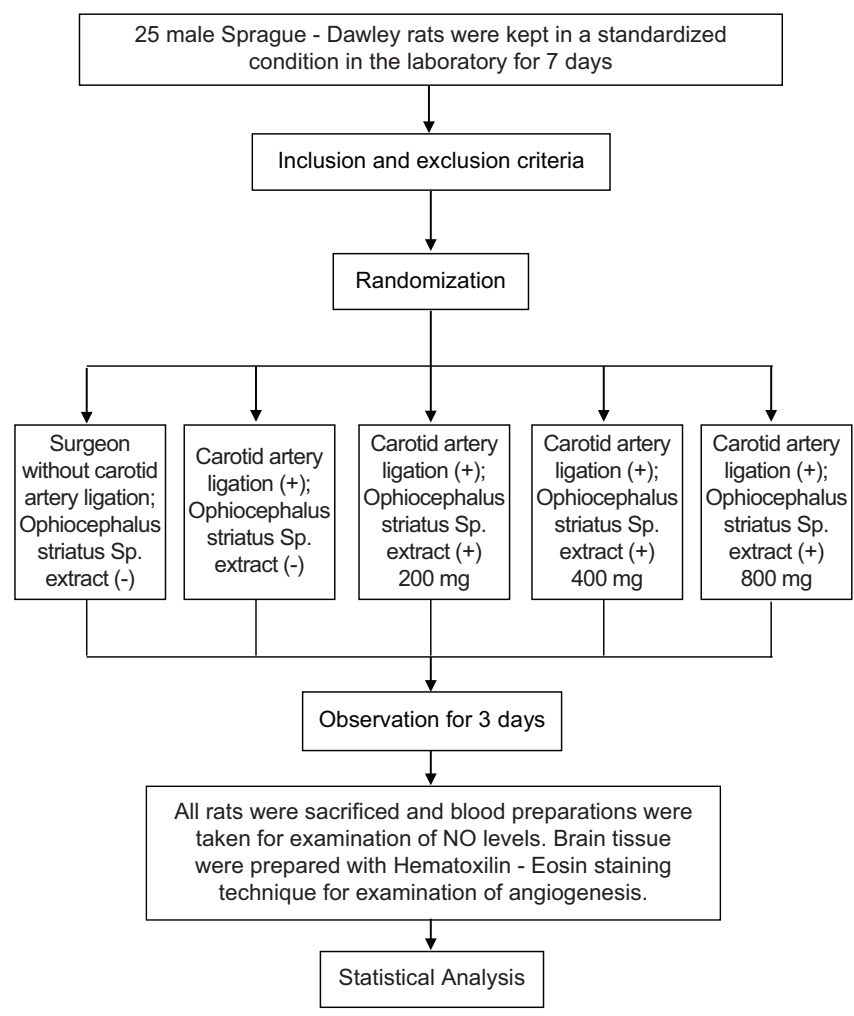

Figure 1: Flowchart of research

\section{Examination of NO levels}

Measurement of NO levels was done through blood collection [6]. The serum was analyzed using the Rat NO ELISA Kit. The examination was carried out on day 3 after administration of $O$. striatus sp. extract.

\section{Histological examination of brain tissue}

The tissue obtained from right hemisphere of the brain. Brain tissue was fixed in a buffered formalin solution for $24 \mathrm{~h}$, then the tissue processed, and implantation was carried out on the paraffin block. The paraffin block was cut to a thickness of 5 $\mu \mathrm{m}$ and placed on the object-glass, depolarized, and dehydrated on the object-glass. The next procedure used a routine hematoxylin-eosin (HE) staining method. Slides were examined under a microscope at $\times 40, \times 100$, and $\times 400$ magnification. Slides were observed in 10 fields and a picture of cerebral angiogenesis was seen [11]. 


\section{Statistical analysis}

All data were analyzed by investigators blinded to the experimental group. Data are presented as mean \pm SD. Data analysis began with the data normality test using the Shapiro-Wilk test. Analysis of increased levels of NO in rat ischemic stroke models after administration of $O$. striatus $\mathrm{sp}$. extract was done by ANOVA test and post hoc Tukey's test. Significance was set at $p<0.05$ [12].

\section{Results}

The experimental animals used in this study were 25 Sprague Dawley strain rats (Rattus norvegicus sp.) with body weight of 305-425 g divided into five groups in five categories. The homogeneity test of $R$. norvegicus Sprague Dawley ischemic stroke models can be seen in Table 1. Results of the Levene test show that $p=0.245(p>0.05)$, it can be stated that the weight of rats ischemic stroke models did not differ significantly.

Table 1: Mean value body weight of Sprague Dawley rats ischemic stroke models before the occlusion of internal and external carotid arteries

\begin{tabular}{lll}
\hline Parameters & Body weight of rats (gram) & p-value \\
\hline Mean value & 360,045 & 0.245 \\
SD & \pm 50.243 & \\
\hline
\end{tabular}

Data in mean $\pm \mathrm{SD}, \mathrm{p}>0.05$

Characteristics of Sprague Dawley rats ischemic stroke models based on histological features can be seen in Figure 2. It showed histological examination of brain tissue before and after occlusion in the internal and external carotid arteries by routine staining technique of HE. There was an increase in the

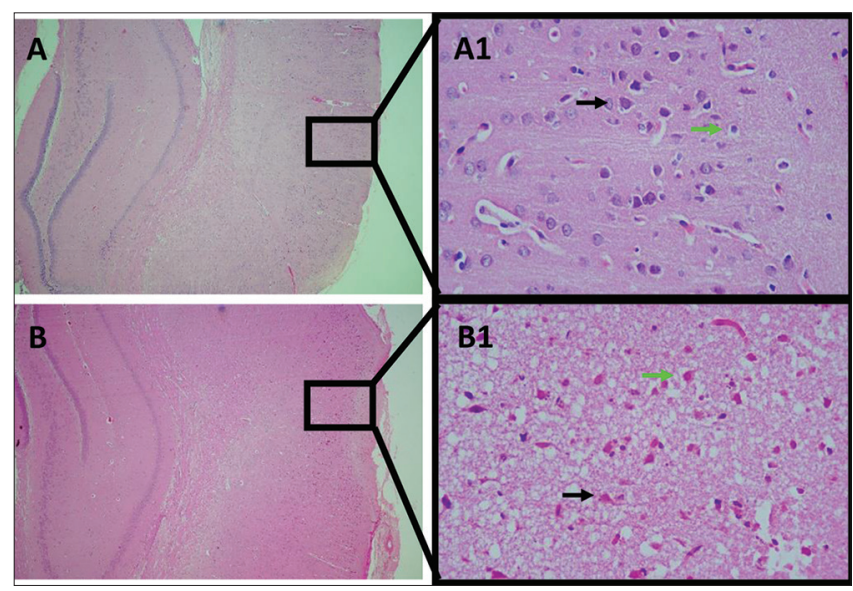

Figure 2: Histological picture of brain tissue due to occlusion in the internal and external carotid arteries. Representation of histological features of rat's brain tissue due to occlusion in internal and external carotid arteries with hematoxylin-eosin staining technique. A. Normal control, A1. $\times 400$ magnification in normal group, B. Occlusion of the artery, B1. $\times 400$ magnification in the occlusion group of the artery. Green arrows indicated microglia cells and black arrows indicated neuron cells. Observed using a Nikon E-100 microscope with magnification of $\times 100$ and $\times 400$, photomicrographs were carried out with a Sony ICLE-A7 camera distribution of microglia cells in the $\mathrm{K}(+)$ group compared to $K(-)$ group. It means that there was activation of the immunological process in the $\mathrm{K}(+)$ group compared to K (-) group (Figure 2).

\section{Increased Level of NO}

Table 2 showed that there was a significant increase level of $\mathrm{NO}$ in the $\mathrm{K}(+)$ group compared to the $K(-)$ group $(p<0.001)$. There was an increase level of $\mathrm{NO}$ in the $\mathrm{P} 1$ group compared to the $\mathrm{K}(+)$ group $(p=0.001)$. There was a significant increase level of $\mathrm{NO}$ in the P2 group compared to the $\mathrm{K}(+)$ group $(\mathrm{p}<$ $0.001)$. There was a significant increase level of $\mathrm{NO}$ in the P3 group compared to the $\mathrm{K}(+)$ group $(\mathrm{p}<0.001)$. Figure 3 showed that administration of $O$. striatus $\mathrm{sp}$. extract in rats ischemic stroke models showed an increase in NO levels in line with increasing doses.

Table 2: Mean value of NO levels with standard deviation ( $\pm S D$ ) and analysis of the different test in each treatment group

\begin{tabular}{|c|c|c|c|}
\hline $\begin{array}{l}\text { Groups } \\
\text { (1) }\end{array}$ & $\begin{array}{l}\text { Mean value (uM) } \\
\text { (2) }\end{array}$ & $\begin{array}{l} \pm \mathrm{SD} \\
\text { (3) }\end{array}$ & $\begin{array}{l}\text { p-value } \\
(4)\end{array}$ \\
\hline $\mathrm{K}(-)$ & 25.4767 & 2.54525 & - \\
\hline $\mathrm{K}(+)$ & 40.2968 & 3.01632 & $<0.001$ \\
\hline $\mathrm{P} 1$ & 51.9067 & 5.30066 & 0.001 \\
\hline P2 & 53.6307 & 4.75324 & $<0.001$ \\
\hline P3 & 59.4290 & 0.87634 & $<0.001$ \\
\hline
\end{tabular}

\section{Angiogenesis of brain tissue after ischemic stroke}

Histological examination of brain tissue after occlusion in the internal and external carotid arteries was done by routine staining technique of HE. There was formation of new blood vessel in the P1, P2, and $\mathrm{P} 3$ groups compared to $\mathrm{K}(+)$ group based on qualitative assessment in the occlusion area of the internal and external carotid arteries (Figure 4).

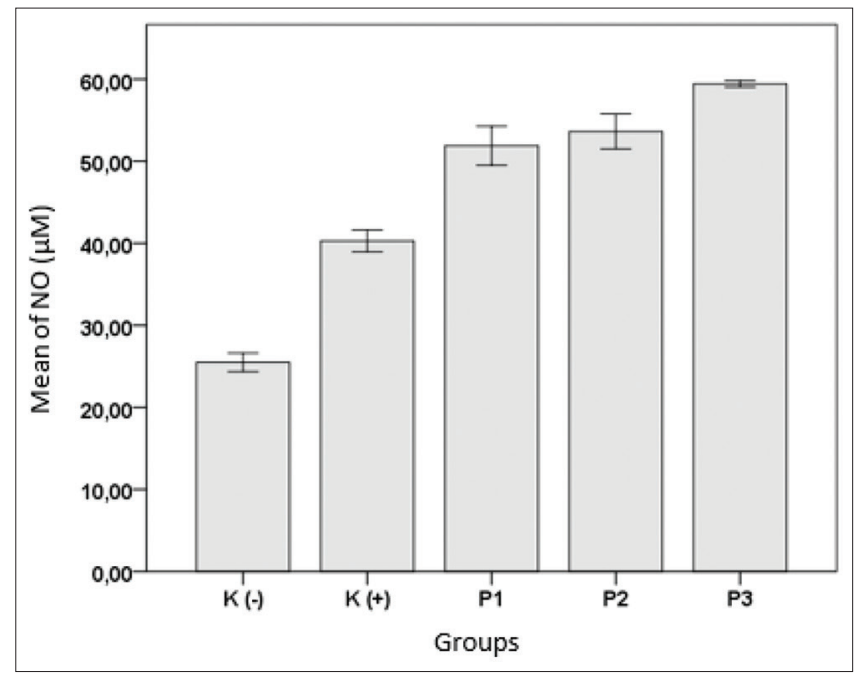

Figure 3: The graphic of mean and analysis of NO levels of ischemic stroke $K_{(+)}$group rat models by administering Ophiocephalus striatus sp. extracts $(P 1, P 2$, and $P 3)$ 


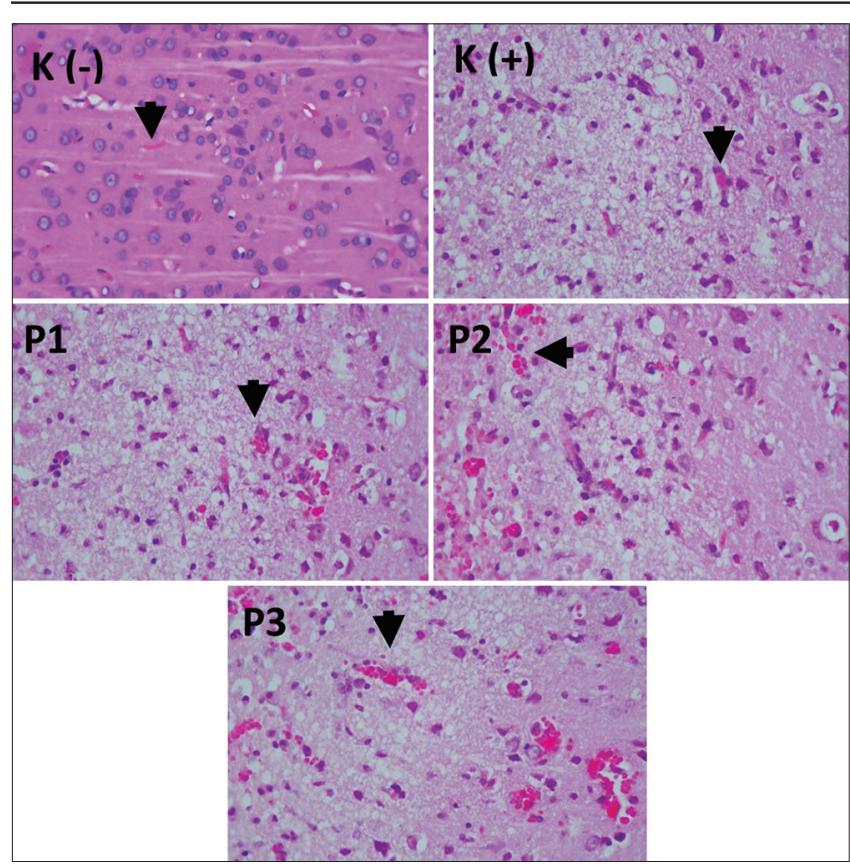

Figure 4: Histological representation of vascularization events in rat's brain tissue in the occlusion of internal carotid artery and external carotid artery with routine staining technique hematoxylin-eosin. K (-) normal group, $\mathrm{K}(+)$ treatment group. P1 Ophiocephalus striatus sp. extract $200 \mathrm{mg} /$ day, P2 Ophiocephalus striatus sp. extract 400 mg/day, P3 Ophiocephalus striatus sp. extract 800 mg/day. Arrows indicated the presence of vascular formation. Observed using a Nikon E-100 microscope at $\times 400$ magnification, photomicrographs were carried out with a Sony ICLE-A7 camera

\section{Discussion}

\section{Histological of Sprague Dawley rat's brain tissue after ligation of internal and external carotid arteries}

The method of stroke induction was done by the UCAO, which is by ligation of the internal and external carotid arteries. Histologic examination of rat's brain tissue with HE routine staining technique after occlusion of the internal carotid arteries and external showed an ischemic area, increased distribution of microglia cells, and also activation of the immunological process in the $\mathrm{K}(+)$ treatment group.

Similar studies related to the method of stroke induction were carried out by occlusion of internal and external carotid arteries to determine the presence of ischemic stroke areas in brain tissue using the HE routine staining technique. The macroscopic test of the Sprague Dawley rat's brain tissue showed that the rats successfully experienced an ischemic stroke [13].

\section{Increased levels of NO in ischemic stroke model rats after administration of $O$. striatus $s p$. extract}

The amino acid contained in $O$. striatus $\mathrm{sp}$. extract in the form of arginine plays a role in the process of NO formation. The results showed that NO is important signaling that regulates blood flow and tissue oxygenation. $\mathrm{NO}$ affects two main aspects of $\mathrm{O}_{2}$ supply and demand that is by regulating vascular tone and blood flow. Abnormalities in NO production and transportation in the vascular system cause disorders related to angiogenesis [14].

The role of $\mathrm{NO}$ in ischemic stroke is very complex, especially in the process of angiogenesis. eNO modulates post-stroke neovascularization, NO which is produced by eNOS through oxidation of L-arginine to L-citrulline has a protective effect which is to reduce platelet aggregation, prevent leukocyte adhesion and increase vasodilation of arteries, blood flow, and regulate contractility [14]. NO from endothelial cells will also cause direct migration and recruiting mural precursor cells to develop blood vessels so that blood vessels mature and stabilize [15]. The administration of $O$. striatus sp. extract in this study was expected to increase the levels of $\mathrm{NO}$ so that the angiogenesis process becomes optimal.

Several studies have identified the factors involved in angiogenesis; vascular endothelial growth factor (VEGF), NO, basic fibroblast growth factor, matrix metalloproteinase (MMP), and prostaglandins. All these factors work together in the process of angiogenesis in the event of ischemia, the combined effect of $\mathrm{NO}$ and VEGF causes vasodilatation and increased vascular permeability that triggers extravasation of plasma proteins for endothelial cell migration that is useful for blood vessel growth [16].

A study by Zhang et al. on increasing angiogenesis by NO through synthesis of VEGF and CGMP in mice after stroke induction showed that compared with the control group, administered exogenous $\mathrm{NO} /$ donor $\mathrm{NO}$ in the form of $(\mathrm{Z})-1-[\mathrm{N}-$ (2-aminoethyl) -N- ( 2-ammonioethyl) aminio] diazen-1ium-1,2-diolate (DETANONOate) at a dose of $0,4 \mathrm{mg} /$ $\mathrm{kg}$ IV $24 \mathrm{~h}$ after stroke induction for 7 days significantly increases vascularization and proliferation of cerebral endothelial cells and also the growth of new blood vessels in the ischemic area. It can be concluded that exogenous NO can cause the process of angiogenesis to increase [17].

The involvement of NO in inducing VEGF synthesis is also supported by research conducted by Dulak et al. in rat's vascular smooth muscle cells (VSMCs). VSMCs are stimulated to produce NO through interleukin (IL) $-1 \beta(10 \mathrm{ng} / \mathrm{mL})$ and lipotransfected VSMCs with plasmid pK endothelial constitutive NOS. The results indicate that endogenous NO increases VEGF synthesis. Positive interaction between endogenous NO with VEGF has implications for endothelial regeneration for angiogenesis [18].

The process of angiogenesis is influenced by various factors, including VEGF expression. VEGF expression is induced in smooth muscle cells by IL-1 $\beta$. 
These cytokines will stimulate the release of iNOS expression and produce NO in VSMCs [19]. It is also found the expression of ecNOS gene expression and producing NO, as well as inducing VEGF expression in VSMCs.

Ma et al. added that physical exercise proven in his research can strengthen microvascular integrity after cerebral ischemia and improve NO synthesis regulation, which also can strengthen blood flow capacity in ischemic cortex areas, reduce infarct volume so that it can improve function return [20].

Tafani et al. in his research on the relationship between reactive oxygen species (ROS), hypoxia, and inflammation explain that in hypoxic conditions, there is increasing of ROS. ROS are free radicals that mediate iNOS to produce NO. One part of ROS is hydrogen peroxide $\left(\mathrm{H}_{2} \mathrm{O}_{2}\right)$ which can cause cell damage, so $\mathrm{NO}$ produced by iNOS by mediating $\mathrm{H}_{2} \mathrm{O}_{2}$ can result in cell death [21].

Increased levels of $\mathrm{NO}$ in this study showed that NO formed was not mediated by iNOS but derived from arginine contained by $O$. striatus $\mathrm{sp}$. extract. Increased levels of NO after administration of extract induced by arginine can also suppress free radicals (ROS/ROS).

The results of study by Armengeo et al. (2003) in clinical and experimental studies with the aim of finding effective neuroprotective strategies proving the involvement of the plasma profile of L-arginine (L-arg) in the incidence of cerebral ischemia, and the relationship of $L$-arginine concentration in blood with infarct volume. Plasma L-arginine profile was analyzed in separate groups, namely (1) in 29 patients seen within $8 \mathrm{~h}$ of onset (median, $4.5 \mathrm{~h}$ ) and (2) in 24 Fischer male rats given subcutaneous therapy or $20 \mathrm{mg} / \mathrm{kg}$ 1400W (specific inducible NO synthase inhibitors) every 8 h for 3 days after permanent cerebral artery occlusion. Plasma L-arginine concentration decreases after ischemic events, both in patients and mice, and peaks between 6 and $24 \mathrm{~h}$. In patients, there was a very high correlation between L-arginine levels in CSF and plasma at $48 \mathrm{~h}(\mathrm{r} 0,85 ; \mathrm{p}<0.001)$. Whereas in mice, a significant decrease in infarct volume was measured 72 hours after permanent cerebral artery occlusion [22].

\section{Angiogenesis in ischemic stroke model rats after administration of $O$. striatus sp. extract}

The blood vessels of the brain have increasingly recognized as a key player who directs brain development, homeostasis and contribute to the pathological process. After the event of ischemic stroke, a reduction in blood flow caused coagulation change and remodeling veins [23].

Decreased supply of circulation to the brain leads to acute systemic influences will result in changes of brain's biochemical order. This is the cause of death of brain tissue. The observation of neovascularization in infarct areas related to stroke survivors showed that angiogenesis is a process of compensation or protection which is also a target of stroke therapy [24].

Angiogenesis is the process of forming new blood vessels in several pathological conditions, including stroke. Angiogenesis is a process of local proliferation, migration and remodeling of existing endothelial cells into new forms of blood vessels. The process includes chemotactic, proteolytic, and mitogenic activities of endothelial cells and interactions between endothelial cells with extracellular molecules and periendothelial supporting cells. An immunohistochemical analysis indicates active angiogenesis on days 2-7. Angiogenesis begins with an increase in vascular permeability, followed by degradation of the basement membrane and extracellular matrix by MMPs. Endothelial cells then begin migration, where there is an accumulation of endothelial cells in the extracellular matrix pathway for the formation of blood vessels. Finally, the lumen contains new blood vessels that form and join the circulation [25].

This study is in line with research by Pudjonarko and Abidin which assessed the effect of snakehead fish extract on serum arginine and the clinical outcome of acute ischemic stroke. There was clinical outcome improvement and enhancement of arginine serum levels in acute ischemic stroke with snakehead fish extract supplementation [5]. In this study, we found the administering $O$. striatus $\mathrm{sp}$. extract improves cerebral angiogenesis of rats ischemic stroke models.

\section{Limitation of study}

This study did not assess the levels of iNOS that are known to play a role in stimulating NO expenditure, which is by knowing the level of iNOS then compared to NO levels, it will be known that NO which has increased comes from arginine and not from iNOS. The assessment of angiogenesis in brain tissue should be done quantitatively, so it can be determined whether it is statistically significant.

\section{Conclusions}

O. striatus $\mathrm{sp}$. extract improves cerebral angiogenesis in ischemic stroke models through the increasing level of NO. This research is expected to contribute to $O$. striatus $\mathrm{sp}$. extract as an alternative therapy for stroke in the future. 


\section{Authors' Contributions}

IN carried out the animal model, organized the data acquisition and analysis, and wrote the manuscript. HS was involved in the conceptualization of the study, data analysis, and acquisition, in addition to contributing to critical appraisal and writing of the manuscript. Ml performed the in vivo stroke animal studies and contributed to data acquisition and analysis. SI was involved in data acquisition and tissue processing as well as statistical analysis. All authors read and approved the final manuscript.

\section{Acknowledgments}

We would like to thank all laboratory staffs for helping in this study.

\section{Ethics Approval and Consent to Participate}

All animal procedures were based on the Helsinki Declaration and approved by the Animal Research Ethics Commission, Faculty of Mathematics and Natural Sciences, University of North Sumatra.

\section{References}

1. Feigin VL, Norrving B, Mensah GA. Global burden of stroke. Circ Res. 2017;120(3):439-48. https://doi.org/10.1161/ circresaha.116.308413 PMid:28154096

2. Hoeben A, Landuyt B, Highley MS, Wildiers $H$, Van Oosterom AT, De Bruijn EA. Vascular endotelial growth factor and angiogenesis. Pharmacol Rev. 2004;56(4):549-80. https:// doi.org/10.1124/pr.56.4.3

PMid:15602010

3. Oentaryo G, Istiati I and Soesilawati P. Acceleration of fibroblast number and FGF-2 expression using Channa striata extract induction during wound healing process: In vivo studies in wistar rats. Dent J (Majalah Kedokteran Gigi). 2016;49(3):125-32. https://doi.org/10.20473/j.djmkg.v49.i3.p125-132

4. Rahayu P, Marcelline F, Sulisttyaningrum E, Suhartono MT. Potential effect of striatin (DLBS0333), a bioactive protein fraction isolated from Channa striata for wound treatment. Asian Pasific J Trop Biomed. 2016;6(12):1001-7. https://doi. org/10.1016/j.apjtb.2016.10.008

5. Pudjonarko D, Abidin Z. Clinical outcome and arginine serum of acute ischemic stroke patients supplemented by Ophiocephalus striatus sp. extract. IOP Conf Ser
Earth Environ Sci. 2018;116(1):012028. https://doi. org/10.1088/1755-1315/116/1/012028

6. Indra MR, Gasmara CP. Metode UCAO (Unilateral serebra artery occlusion) meningkatkan kadar MMP-9 jaringan otak pada model tikus stroke iskemik. Malang Neurol J. 2016;2(2):47-51. https://doi.org/10.21776/ub.mnj.2016.002.02.1

7. Gandin C, Widmann C, Lazdunski M, Heurteaux C. MLC901 favors angiogenesis and associated recovery after ischemic stroke in mice. Cerebrovasc Disc. 2016;42(1-2):139-54. https:// doi.org/10.1159/000444810

PMid:27099921

8. Bederson JB, Pitts LH, Tsuji M, Nishimura MC, Davis RL, Bartkowski H. Rat middle serebral artery occlusion: Evaluation of the model and development of a neurologic examination. Stroke. 1986;17(3):472-6. https://doi.org/10.1161/01.str.17.3.472 PMid:3715945

9. Siswanto A, Dewi N, Hayatie L. Effect of Haruan (Channa striata) extract on fibroblast cells count in wound healing. $J$ Dentomaxillofac Sci. 2016;1(2):89-94. https://doi.org/10.15562/ jdmfs.v1i2.3

10. Norhalifah N, Rahmawanty D, Nurlely N. Uji efektivitas ekstrak air ikan haruan (Channa striata) asal Kalimantan selatan terhadap bleeding time dan clotting time secara in vivo. Med Farm. 2016;13(2):237-49. https://doi.org/10.24198/mfarmasetika. v4i0.25880

11. Nair $A B$, Jacob $S$. A simple practice guide for dose conversion between animals and human. J Basic Clin Pharm. 2016;7(2):2731. https://doi.org/10.4103/0976-0105.177703 PMid:27057123

12. Notoadmojo S. Metodologi Penelitian Kesehatan. Jakarta: PT Rineka Cipta; 2012.

13. Sahid NA, Hayati F, Rao CV, Ramely R, Sani I, Dzulkarnaen A, et al. Snakehead consumption enhances wound healing? From tradition to modern clinical practice: A prospective randomized controlled trial. Evid Based Complement Altern Med. 2018;2018:3032790. https://doi.org/10.1155/2018/3032790

14. Chen J, Zacharek A, Zhang C, Jiang H, Li Y, Roberts C, et al. Endotelial nitric oxide synthase regulates brain-derived neurotrophic factor expression and neurogenesis after stroke in mice. J Neurosci. 2005;25(9):2366-75. https://doi.org/10.1523/ jneurosci.5071-04.2005

PMid: 15745963

15. Chen K, Pittman RN, Popel AS. Nitric oxide in the vasculature: Where does it come from and where does it go? A quantitative perspective. Antioxid Redox Signal. 2008;10(7):1185-95. https:// doi.org/10.1089/ars.2007.1959

PMid:18331202

16. Carmeliet $P$, Collen D. Molecular basis of angiogenesis. Role of VEGF and VE-Cadherin. Ann N Y Acad Sci. 2000;902:24964; discussion 262-4. https://doi.org/10.1111/j.1749-6632.2000. tb06320.x

PMid: 10865845

17. Zhang R, Wang L, Zhang L, Chen J, Zhu Z, Zhang Z, et al. Nitric oxide enhances angiogenesis via the synthesis of vascular endothelial growth factor and cGMP after stroke in the rat. Circ Res. 2003;92(3):308-13. https://doi.org/10.1161/01. res.0000056757.93432.8c

PMid: 12595343

18. Dulak J, Jozkowicz A, Dembinska-Kiec A, Guevara I, Zdzienicka A, Zmudzinska-Grochot D, et al. Nitric oxide induces the synthesis of vascular endothelial growth factor by rat vascular smooth muscle cells. J Am Heart Assoc. 2013;20(3):659-66. https://doi.org/10.1161/01.atv.20.3.659 PMid:10712388

19. Li J, Perrella MA, Tsai JC, Yet SF, Hsieh CM, Yoshizumi M, 
et al. Induction of vascular endothelial growth factor gene expression by interleukin-1 in rat aortic smooth muscle cells. J Biol Chem. 1995;270(1):308-12. https://doi.org/10.1074/ jbc.270.1.308

PMid:7814392

20. Ma Y, Qiang L, He M. Exercised therapy augments the ischemic-induced proangiogenic state and results in sustained improvement after stroke. Int J Mol Sci. 2013;14(4):8570-84. https://doi.org/10.3390/ijms14048570

PMid:23598418

21. Tafani M, Sansone L, Limana F, Arcangeli T, De Santis E, Polese $\mathrm{M}$, et al. The interplay of reactive oxygen species, hypoxia, inflammation and sirtuins in cancer initiation and progression. Oxid Med Cell Longev. 2016;2016:3907147. https://doi.org/10.1155/2016/3907147

PMid:26798421

22. Armengou A, Hurtado O, Leira R, Obon M, Pascual C,
Moro MA, et al. L-Arginine levels in blood as marker of nitric oxide-mediated brain damage in acute stroke: A clinical and experimental study. J Cereb Blood Flow Metab. 2003;23(8):97884. https://doi.org/10.1097/01.wcb.0000080651.64357.c PMid: 12902842

23. Liu J, Wang Y, Akamatsu Y, Lee CC, Stetler RA, Lawton MT. Vascular remodeling after ischemic stroke: Mechanism and therapeutic potentials. Prog Neuobiol. 2014;115:138-56. https:// doi.org/10.1016/j.pneurobio.2013.11.004

PMid:24291532

24. Chopp M, Li Y, Chen J, Zhang R, Zhang Z. Brain repair and recovery from stroke. Eur Neurol. 2008;3(1):2-5.

25. Majewska I, Gendaszewska-Darmach E. Proangiogenic activity of plant extracts in accelerating wound healing a new face of old phytomedicines. 2011;58(4):449-60. https://doi.org/10.18388/ abp.2011_2210

PMid:22030557 